Volume 8. No. 4, April 2020

International Journal of Emerging Trends in Engineering Research

Available Online at http://www.warse.org/IJETER/static/pdf/file/ijeter51842020.pdf

https://doi.org/10.30534/ijeter/2020/51842020

\title{
Investigation on Kiln dust- Bentonite Composite Behavior
}

\author{
Mahdi Keramatikerman ${ }^{1}$, Amin Chegenizadeh ${ }^{2}$, Hamid Nikraz $^{3}$ \\ ${ }^{1}$ Engineer, Arup Australia, 61-73 Sturt Street, Suncorp Tower, Townsville QLD 4810, Australia. \\ mahdi.keramati@arup.com \\ ${ }^{2}$ Senior Lecturer, Department of Civil Engineering, Curtin University of Technology, Kent Street, Bentley, Perth, \\ Western Australia 6102, Australia. amin.chegenizadeh@ curtin.edu.au \\ ${ }^{3}$ Professor, Department of Civil Engineering, Curtin University of Technology, Kent Street, Bentley, Perth, \\ Western Australia 6102, Australia. h.nikraz@curtin.edu.au
}

\begin{abstract}
This study investigates effect of addition of Kiln dust and fiber on shear behavior of the bentonite clay. To do so, a series of direct shear tests were defined and were tested on the composite materials. A constant value of $2 \%$ for fiber, and 5 , 10 , and $15 \%$ kiln dust (KD) was mixed with bentonite clay and the optimum moisture content (OMC) and the maximum dry density (MDD) was recorded at the first stage. In the second stage, specimens were prepared according to the acquired parameters in the compaction testing and the test conducted under three normal stress of 100, 150, and 200 $\mathrm{kPa}$. The results showed that increasing the kiln dust improved shear behavior of the bentonite clay.
\end{abstract}

Key Words: Direct Shear; Clay; Fiber; Kiln Dust

\section{INTRODUCTION}

Soil behavior in many ways being investigated such as [1,2]. Bentonite and clayey materials investigated in terms of their characteristic [3]. Soil stabilization using additives is a common practice in geotechnical engineering. Previous studies showed that application of fiber [4-13], fly ash [14-16], slag [17], and sawdust [18] in conjunction with different geomaterials. These studies conducted on various soil mechanical behavior such as unconfined compressive strength (UCS) [19-20], liquefaction [21-22], tire and waste [23-27] shear strength [28-30], consolidation, permeability [31-32]. While the applications of kiln dust (KD) were evident in literature [33-40], the review of the previous studies showed that no studies conducted to investigate shear behavior of the soil composite of kiln dust (KD) and fiber when mixed with clay. Fabric of soil is an important factor in stress concept [41-46] and therefore bentonite due its complex nature requires more attention. This work is continuation of previous works on fibers example $[4-6,10,11,13]$ and waste and byproduct application in Curtin university example [14, 17,18, ,26-27]. Direct shear test is a basic but important to investigate shearing behavior of the composites in experimental geomechanics. Different normal loading can be applied on the specimens that can be representative for the soil under different loading situations. In a direct shear test, soil sample can be sheared at soaked and unsoaked conditions. This test also is representative for modelling slopes and embankments. The peak shear strength is a value that represents the highest shear strength of the soil against a specific normal stress. Running the test for a longer shear displacement can be representative for a residual shear strength that is used in landslide and ring shear testing is a more suitable experiment for this purpose. Shear displacement rate is also another important parameter. Selecting a higher shear rate value may lead to inaccurate outcomes and selection of a very low shear rate may lead to a time taking test.

\section{MATERIALS}

The following materials have been used to perform the experiments in this study.

\subsection{Clay}

Bentonite was selected as employed clay from a local source in Perth, Western Australia. The bentonite characteristics can be found in Table 1.

Table 1: Bentonite properties

\begin{tabular}{|l|l|}
\hline Liquid Limit (LL)\% & 102 \\
\hline Plastic Limit (PL)\% & 31 \\
\hline Plasticity index (PI)\% & 71 \\
\hline
\end{tabular}

\subsection{Kiln Dust}

Specific gravity of rice husk is $2.03 \mathrm{~g} / \mathrm{cm}^{3}$. Average grain size was $7.5 \mu \mathrm{m}$.

\subsection{Fiber}

Propylene fibre (PF) was employed. The length of fiber was $5 \mathrm{~mm}$.

\section{TEST PROGRAM}

A series of direct shear tests were conducted on the specimens mixed with the kiln dust (KD) and fiber. 2\% fiber and 5, 10, 
and $15 \%$ kiln dust were utilized. The compaction tests were conducted on the mixtures to achieve the optimum moisture content (OMC) and the maximum dry density (MDD). Table 2 shows the testing program used in this study. The device which was used in this study can be seen in Figure 1.

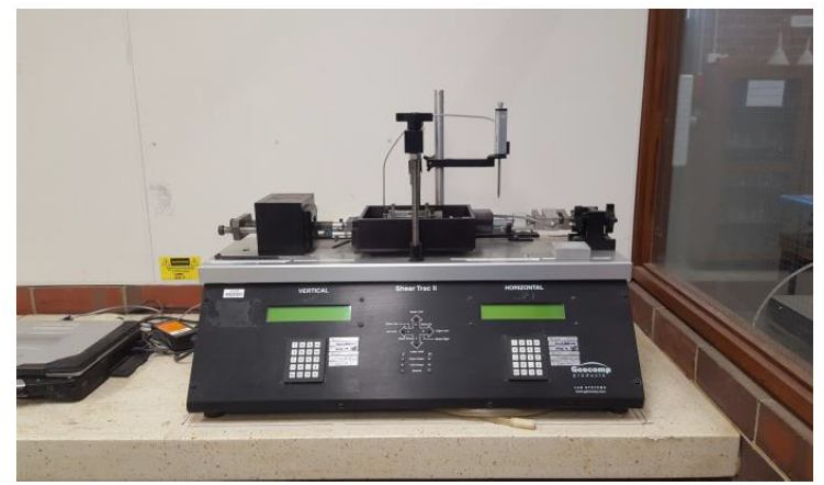

Figure 1 :Employed Direct Shear

Table 2: Testing program utilized in this study

\begin{tabular}{|c|c|c|}
\hline Sample ID & Kiln Dust \% & Fiber (\%) \\
\hline B-k5 & 5 & 2 \\
\hline B-k10 & 10 & 2 \\
\hline B-k15 & 15 & 2 \\
\hline
\end{tabular}

\section{TEST RESULTS}

\subsection{Compaction Results}

Compaction results were presented in Table 3. Also, Figure 2 and Figure 3 show results of the compaction tests.

Table 3: Results of compaction rests.

\begin{tabular}{|c|c|c|c|c|}
\hline $\begin{array}{c}\text { Sample } \\
\text { ID }\end{array}$ & $\begin{array}{c}\text { Kiln } \\
\text { Dust \% }\end{array}$ & $\begin{array}{c}\text { Fiber } \\
(\%)\end{array}$ & OMC \% & MDD (gr/cm3) \\
\hline B-k5 & 5 & 2 & 50.6 & 1.25 \\
\hline B-k10 & 10 & 2 & 53.1 & 1.23 \\
\hline B-k15 & 15 & 2 & 58 & 1.22 \\
\hline
\end{tabular}

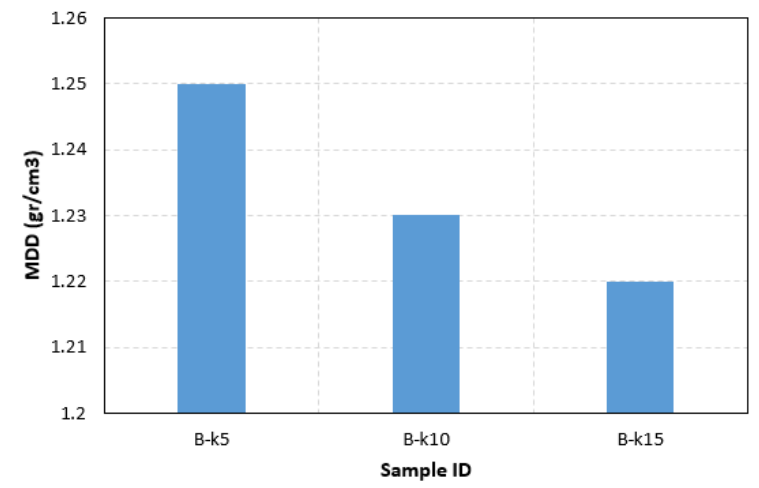

Figure 2: MDD results

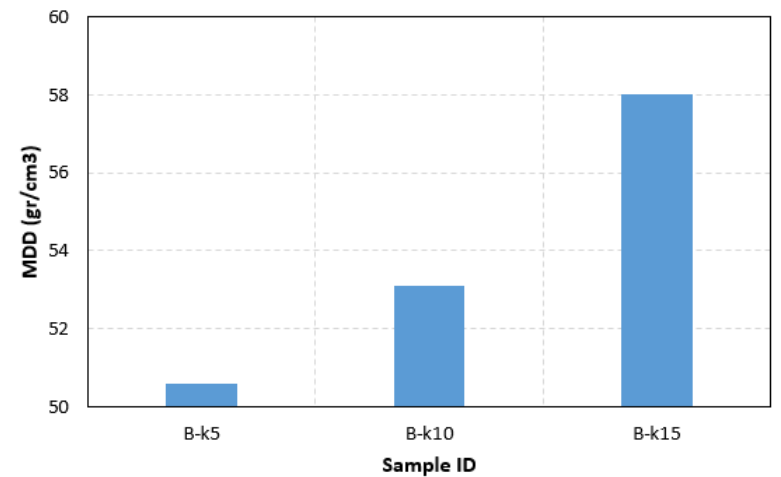

Figure 3: OMC Results

\subsection{Direct Shear Tests}

Direct shear testing results were presented in figure 4,5 , and 6.

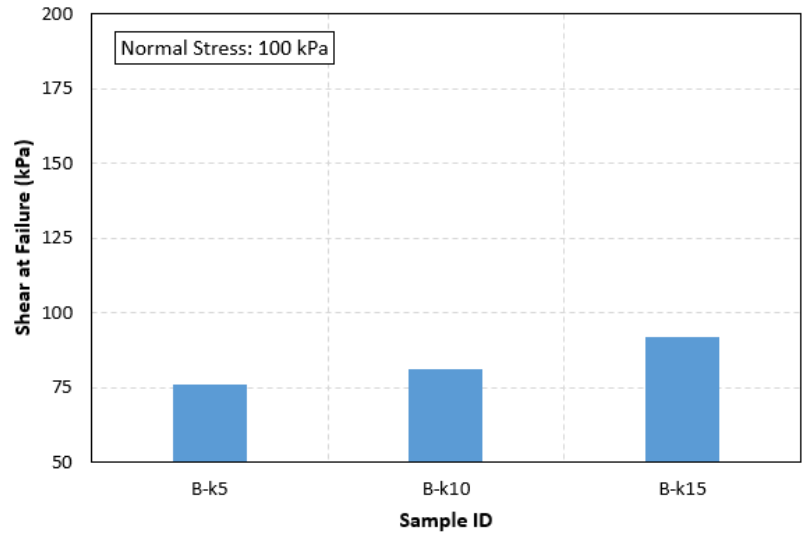

Figure 4: Direct shear tests under $100 \mathrm{kPa}$ normal stress

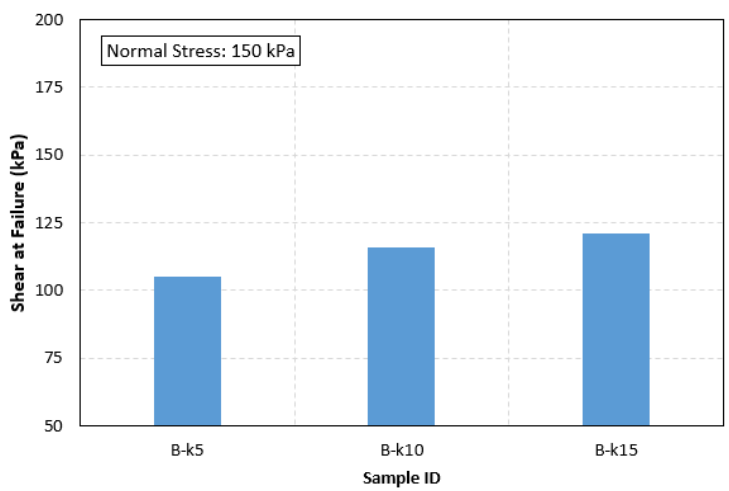

Figure 5: Direct shear tests under $150 \mathrm{kPa}$ normal stress 


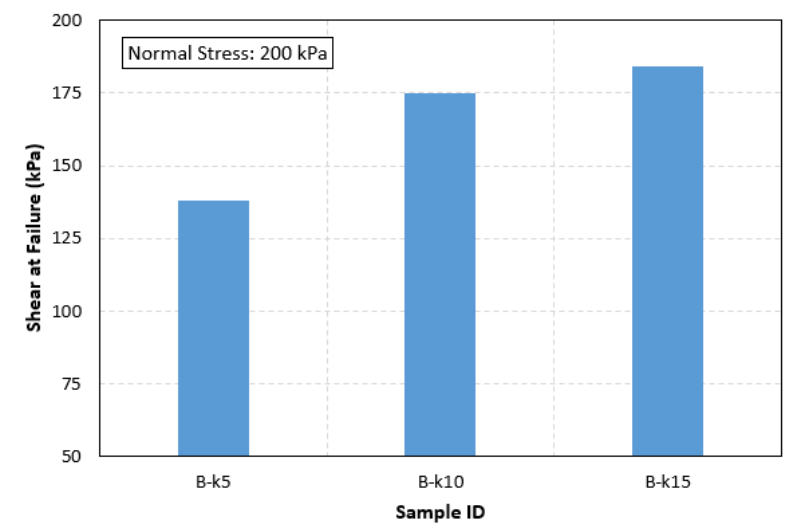

Figure 6: Direct shear tests under $200 \mathrm{kPa}$ normal stress

\section{CONCLUSION}

Results showed that increasing the kiln dust contents increased the OMC and reduced the MDD. Also, the results showed that increasing the KD dosage improved the shear strength of the soil under three normal stresses of 100, 150, and $200 \mathrm{kPa}$. This shows a similar trend across all normal stresses.

\section{REFERENCES}

[1] Al-rkaby, A.H.J., Chegenizadeh, A., Nikraz, H.R. Cyclic behavior of reinforced sand under principal stress rotation Journal of Rock Mechanics and Geotechnical Engineering 2017 9(4), pp. 585-598 https://doi.org/10.1016/j.jrmge.2017.03.010

[2] Chegenizadeh A, Ghadimi B, Nikraz H, Simsek M. A novel two-dimensional approach to modelling functionally graded beams resting on a soil medium. Structural Engineering and Mechanics. 2014;51(5):727-41

[3] Liu SY, Shao GH, Du YJ, Cai GJ. Depositional and geotechnical properties of marine clays in Lianyungang, China. Engineering Geology. 2011;121(1):66-74. https://doi.org/10.1016/j.enggeo.2011.04.014

[4] Chegenizadeh, A., Nikraz, H. Investigation on strength of fiber reinforced clay Advanced Materials Research 2011.261-263, pp. 957-963.

[5] Chegenizadeh, A. and H. Nikraz, Composite Soil: Fiber Inclusion and Strength, Journal of Advanced Materials Research 2011.1646

[6] Chegenizadeh, A. and H. Nikraz, Composite Clayey Sand and Short Fiber, Advanced Materials Research 2012.383, 2764-2769

[7] Miller B, Muri P, Rebenfeld L. A microbond method for determination of the shear strength of a fiber/resin interface. Composites Science and Technology. 1987 Jan 1;28(1):17-32 https://doi.org/10.1016/0266-3538(87)90059-5

[8] Ramkrishnan R, Sruthy MR, Sharma A, Karthik V. Effect of random inclusion of sisal fibres on strength behavior and slope stability of fine grained soils.
Materials Today: Proceedings. 2018;5(11, Part 3):25313-22.

https://doi.org/10.1016/j.matpr.2018.10.334

[9] Al-Rkaby AHJ, Chegenizadeh A, Nikraz H. Anisotropic strength of large scale geogrid-reinforced sand: experimental study Soils and foundations 2017.57 (4), 557-574 https://doi.org/10.1016/j.sandf.2017.03.008

[10] Chegenizadeh, A., Nikraz, H. Investigation on compaction characteristics of reinforced soil .

Advanced Materials Research 2011 261-263, pp. 964-968

[11] Chegenizadeh, A., Nikraz, H. Shear test on reinforced clay Advanced Materials Research 2011, 250-253, pp. 3223-3227

[12] Danso H, Manu D. Influence of coconut fibres and lime on the properties of soil-cement mortar. Case Studies in Construction Materials. 2020;12:e00316.

[13] Chegenizadeh A, Nikraz H. Permeability test on reinforced clayey sand. World Academy of Science, Engineering and Technology. 2011;54:130-3.

[14] Keramatikerman M, Chegenizadeh A, Nikraz H. Experimental study on effect of fly ash on liquefaction resistance of sand Soil Dynamics and Earthquake Engineering,2017. 93, 1-6 https://doi.org/10.1016/j.soildyn.2016.11.012

[15] Prabakar J, Dendorkar N, Morchhale RK. Influence of fly ash on strength behavior of typical soils. Construction and Building Materials. 2004 May 1;18(4):263-7.

[16] Phani Kumar BR, Sharma RS. Effect of fly ash on engineering properties of expansive soils. Journal of Geotechnical and Geoenvironmental Engineering. $2004 \mathrm{Jul} ; 130$ (7):764-7.

[17] Sabbar AS, Chegenizadeh A, Nikraz H. Static liquefaction of very loose sand-slag-bentonite mixtures. Soils and Foundations. 2017 Jun 1;57(3):341-56.

[18] Keramatikerman, M., Chegenizadeh, A., \& Nikraz, H. An investigation into effect of sawdust treatment on permeability and compressibility of soil-bentonite slurry cut-off wall. Journal of Cleaner Production, 2017.162, 1-6.

[19] Guo X, Shi H, Dick WA. Compressive strength and microstructural characteristics of class $\mathrm{C}$ fly ash geopolymer. Cement and Concrete Composites. 2010 Feb 1;32(2):142-7. https://doi.org/10.1016/j.cemconcomp.2009.11.003

[20] Chindaprasirt P, Jaturapitakkul C, Sinsiri T. Effect of fly ash fineness on compressive strength and pore size of blended cement paste. Cement and Concrete Composites. 2005 Apr 1;27(4):425-8.

[21] Keramatikerman M, Chegenizadeh A. Effect of particle shape on monotonic liquefaction: Natural and crushed sand. Experimental Mechanics. 2017 Oct 1;57(8):1341-8. 
[22] Chegenizadeh, A., Keramatikerman, M., \& Nikraz, H. Liquefaction resistance of fibre reinforced low-plasticity silt. Soil Dynamics and Earthquake Engineering,2018. 104, 372-377. https://doi.org/10.1016/j.soildyn.2017.11.004

[23] Chegenizadeh, A., Keramatikerman, M., Dalla Santa, G., \& Nikraz, H. Influence of recycled tyre amendment on the mechanical behaviour of soil-bentonite cut-off walls. Journal of cleaner production, 2018.177, 507-515

[24] Liu L, Cai G, Zhang J, Liu X, Liu K. Evaluation of engineering properties and environmental effect of recycled waste tire-sand/soil in geotechnical engineering: A compressive review. Renewable and Sustainable Energy Reviews. 2020;126:109831. https://doi.org/10.1016/j.rser.2020.109831

[25] Abbaspour M, Aflaki E, Moghadas Nejad F. Reuse of waste tire textile fibers as soil reinforcement. Journal of Cleaner Production. 2019;207:1059-71.

[26] Chegenizadeh A, Keramatikerman M, Panizza S, Nikraz H. Effect of powdered recycled tire on sulfate resistance of cemented clay. Journal of Materials in Civil Engineering. 2017 Oct 1;29(10):04017160.

[27] Amiralian S, Budihardjo MA, Chegenizadeh A, Nikraz $H$. Study of scale effect on strength characteristic of stabilised composite with sewage sludge-Part A: Preliminary study. Construction and Building Materials. 2015 Apr 1;80:339-45.

[28] Zhang C, Wang X, Zou X, Tian J, Liu B, Li J, et al. Estimation of surface shear strength of undisturbed soils in the eastern part of northern China's wind erosion area. Soil and Tillage Research. 2018;178:1-10.

[29] Fredlund DG, Morgenstern NR, Widger RA. The shear strength of unsaturated soils. Canadian geotechnical journal. 1978 Aug 1;15(3):313-21. https://doi.org/10.1139/t78-029

[30] Barton N, Choubey V. The shear strength of rock joints in theory and practice. Rock mechanics. 1977 Dec 1;10(1-2):1-54.

[31] Beard DC, Weyl PK. Influence of texture on porosity and permeability of unconsolidated sand. $A A P G$ bulletin. 1973 Feb 1;57(2):349-69.

[32] van Verseveld CJW, Gebert J. Effect of compaction and soil moisture on the effective permeability of sands for use in methane oxidation systems. Waste Management. 2020;107:44-53.

[33]Kadhim, A.S., A.A. Atiyah, and S.A. Salih, Properties of self-compacting mortar containing nano cement kiln dust. Materials Today: Proceedings, 2020. 20: p. 499-504. https://doi.org/10.1016/j.matpr.2019.09.177

[34]Abd Ali, Z.T., et al., Predominant mechanisms for the removal of nickel metal ion from aqueous solution using cement kiln dust. Journal of Water Process Engineering, 2020. 33: p. 101033.
[35]Abdel-Gawwad, H.A., et al., Sustainable disposal of cement kiln dust in the production of cementitious materials. Journal of Cleaner Production, 2019. 232: p. 1218-1229.

[36]Rimal, S., R.K. Poudel, and D. Gautam, Experimental study on properties of natural soils treated with cement kiln dust. Case Studies in Construction Materials, 2019. 10: p. e00223.

[37]Arulrajah, A., et al., Cement kiln dust and fly ash blends as an alternative binder for the stabilization of demolition aggregates. Construction and Building Materials, 2017. 145: p. 218-225.

[38]Al-Rezaiqi, J., A. Alnuaimi, and A.W. Hago, Efficiency factors of burnt clay and cement kiln dust and their effects on properties of blended concrete. Applied Clay Science, 2018. 157: p. 51-64. https://doi.org/10.1016/j.clay.2018.01.040

[39]Arulrajah, A., et al., Effect of lime kiln dust as an alternative binder in the stabilization of construction and demolition materials. Construction and Building Materials, 2017. 152: p. 999-1007.

[40]Amouzadeh Omrani, M. and A. Modarres, Emulsified cold recycled mixtures using cement kiln dust and coal waste ash-mechanical-environmental impacts. Journal of Cleaner Production, 2018. 199: p. 101-111.

[41] Al-Rkaby AHJ, Chegenizadeh A, Nikraz H. Directional-dependence in the mechanical characteristics of sand: a Review International Journal of Geotechnical Engineering 2016. 10 (5), 499-509

[42] Sun Q, Zheng J. Two-dimensional and three-dimensional inherent fabric in cross-anisotropic granular soils. Computers and Geotechnics. 2019;116:103197. https://doi.org/10.1016/j.compgeo.2019.103197

[43] Yimsiri S, Soga K. Effects of soil fabric on behaviors of granular soils: Microscopic modeling. Computers and Geotechnics. 2011;38(7):861-74.

[44] Mohd Fakri Muda, Saffuan Wan Ahmad, Fadhluhartini Muftah, Mohd Syahrul Hisyam Mohd Sani, Mechanical Behaviour of Mortar Made with Washed Bottom Ash as Sand Replacement, International Journal of Emerging Trends in Engineering Research,2019 7 (9).

[45] Liu X, Liu E, Zhang D, Zhang G, Yin X, Song B. Study on effect of coarse-grained content on the mechanical properties of frozen mixed soils. Cold Regions Science and Technology. 2019;158:237-51.

[46] Mareschal L, Turpault MP, Ranger J. Effect of granite crystal grain size on soil properties and pedogenic processes along a lithosequence. Geoderma. 2015;249-250:12-20. 